\title{
Evaluation of Transition Points between Different Solid Phases in Aqueous Media
}

\author{
Anna M. Michałowska-Kaczmarczyk ${ }^{1}$, Tadeusz Michałowski2* \\ ${ }^{1}$ Department of Oncology, The University Hospital in Cracow, Cracow, Poland \\ ${ }^{2}$ Faculty of Engineering and Chemical Technology, Technical University of Cracow, Cracow, Poland \\ Email: michalot@o2.pl
}

Received 3 July 2014; revised 3 August 2014; accepted 10 August 2014

Copyright (C) 2014 by authors and Scientific Research Publishing Inc.

This work is licensed under the Creative Commons Attribution International License (CC BY).

http://creativecommons.org/licenses/by/4.0/

(c) (9) Open Access

\section{Abstract}

A uniform procedure is suggested for calculation of the $\mathrm{pH}_{t}$ value(s) separating equilibrium solid phases in $\mathrm{pH}$ scale, at an excess of the precipitating agent. The $\mathrm{pH}_{t}$ value, related to pairs of precipitates formed from the species $\operatorname{Me}(\mathrm{OH})_{i}^{+u-i}(i=1, \cdots, p)$ and $\mathrm{H}_{j} \mathrm{~L}^{+j-n} \quad(j=1, \cdots, q)$, fulfils the relation $n \cdot p H+p \mathrm{~L}=F$, where $F$ is a constant value involving $p K_{\text {so's }}$ 's for solubility products ( $K_{s o}$ 's) of these precipitates, and the equilibrium data, related to the species composing these precipitates.

Keywords

Electrolytic Systems, Precipitates, pH-Intervals

\section{Introduction}

Some species are able to form different solid phases in aqueous media whose composition depends on $\mathrm{pH}$-value of these media. In particular, this was indicated for the systems obtained after introducing the ternary salts such as struvite [1] or dolomite [2] into pure water or aqueous solution of a strong base in presence/absence of $\mathrm{CO}_{2}$, originating e.g. from air. Full physicochemical knowledge was involved in the algorithms used for calculations made according to iterative computer programs related to redox or non-redox, mono- or two-phase systems [3]-[8].

This paper concerns calculations related to two-phase systems, and made with use of Excel spreadsheets. It refers to location of different equilibrium solid phases within defined $\mathrm{pH}$-intervals [9]-[11]. The search of these $\mathrm{pH}$-intervals is based on the simplified calculation procedure. The $\mathrm{pH}$-values separating these intervals are

*Corresponding author.

How to cite this paper: Michałowska-Kaczmarczyk, A.M. and Michałowski, T. (2014) Evaluation of Transition Points between Different Solid Phases in Aqueous Media. Journal of Analytical Sciences, Methods and Instrumentation, 4, 87-94.

http://dx.doi.org/10.4236/jasmi.2014.43012 
named as transition $(t)$ points, and denoted as $\mathrm{pH}_{t}$.

\section{Formulation of the Transition Points}

Let the precipitates $\mathbf{M e}_{\boldsymbol{a}}\left(\mathbf{H}_{k} \mathbf{L}\right)_{b}$ and $\mathbf{M e}_{c}\left(\mathbf{H}_{m} \mathbf{L}\right)_{d}$, characterized by solubility products:

$$
\begin{aligned}
& {\left[\mathrm{Me}^{+u}\right]^{a} \cdot\left[\mathrm{H}_{k} \mathrm{~L}^{+k-n}\right]^{b}=K_{s o, a b}} \\
& {\left[\mathrm{Me}^{+u}\right]^{c} \cdot\left[\mathrm{H}_{m} \mathrm{~L}^{+m-n}\right]^{d}=K_{s o, c d}}
\end{aligned}
$$

be two equilibrium solid phases formed in an aqueous system involving $\mathrm{Me}^{+u}$ and $\mathrm{L}^{-n}$ ions, together with the $\mathrm{Me}(\mathrm{OH})_{i}^{+u-i} \quad(i=1, \cdots, p)$ and $\mathrm{H}_{j} \mathrm{~L}^{+j-n} \quad(j=1, \cdots, q)$ species resulting from hydrolytic phenomena; other (possible) soluble complexes formed between the related species are omitted (not involved) in the related balances. The numbers: $a, b, c, d, u, n, k$ and $\mathrm{m}$ in (1) and (2) satisfy the conditions of electro neutrality of the corresponding precipitates:

$$
\begin{gathered}
a u=b(n-k) \rightarrow b k=b n-a u \\
c u=d(n-m) \rightarrow d m=d n-c u, c u+d m=d n
\end{gathered}
$$

We assume that the Me-species are precipitated with an excess of the L-species; this excess is expressed by the molar concentration:

$$
C_{\mathrm{L}}^{\cdot}=\sum_{j=0}^{q}\left[\mathrm{H}_{j} \mathrm{~L}^{+j-n}\right]
$$

If the protonated species do not exist, then $C_{\mathrm{L}}^{\bullet}=\left[\mathrm{L}^{-n}\right]$. Applying the stability constants $K_{j}^{\mathrm{H}}$ of the proto-complexes, $\left[\mathrm{H}_{j} \mathrm{~L}^{+j-n}\right]=K_{j}^{\mathrm{H}} \cdot\left[\mathrm{H}^{+1}\right]^{j}\left[\mathrm{~L}^{-n}\right]$, we denote:

$$
C_{\mathrm{L}}^{\bullet}=\left[\mathrm{L}^{-n}\right] \cdot z_{\mathrm{L}}
$$

where

$$
\mathrm{z}_{\mathrm{L}}=1+\sum_{j=1}^{q} K_{j}^{\mathrm{H}} \cdot\left[\mathrm{H}^{+1}\right]^{i}
$$

and $K_{0}^{\mathrm{H}} \equiv 1$. Assuming $C_{\mathrm{L}}^{\bullet}=$ const, and the equilibrium solid phases: $\mathbf{M e}_{\boldsymbol{a}}\left(\mathbf{H}_{\boldsymbol{k}} \mathbf{L}\right)_{b}$ (at $\left.\mathrm{pH}<\mathrm{pH}_{t 1}\right)$ and $\mathbf{M e}_{c}\left(\mathbf{H}_{m} \mathbf{L}\right)_{d}$ (at $\mathrm{pH}>\mathrm{pH}_{t 1}$ ), we state that at transitional $\mathrm{pH}=\mathrm{pH}_{t 1}$ value, the solubility products: $K_{\mathrm{so}, a b}$ and $K_{s o, c d}$ are fulfilled simultaneously, and then from (1) and (2) we get:

$$
\left[\mathrm{H}^{+1}\right]^{b k c-d m a} \cdot\left[\mathrm{L}^{-n}\right]^{b c-a d} \cdot\left(K_{k}^{\mathrm{H}}\right)^{b c} \cdot\left(K_{m}^{\mathrm{H}}\right)^{-a d}=\left(K_{s o, a b}\right)^{c} \cdot\left(K_{s o, c d}\right)^{-a}
$$

Applying in (8) the relations (3) and (4), we have $b k c-d m a=n(b c-a d)$ and then, by turns,

$$
\begin{gathered}
{\left[\mathrm{H}^{+1}\right]^{n(b c-a d)} \cdot\left[\mathrm{L}^{-n}\right]^{b c-a d} \cdot\left(K_{k}^{\mathrm{H}}\right)^{b c} \cdot\left(K_{m}^{\mathrm{H}}\right)^{-a d}=\left(K_{s o, a b}\right)^{c} \cdot\left(K_{s o, c d}\right)^{-a}} \\
n \cdot \mathrm{pH}+\mathrm{pL}=\frac{c \cdot p K_{s o, a b}-a \cdot p K_{s o, c d}-b c \cdot \log K_{k}^{\mathrm{H}}+a d \cdot \log K_{m}^{\mathrm{H}}}{b c-a d}
\end{gathered}
$$

where $\mathrm{pH}=-\log \left[\mathrm{H}^{+1}\right], \mathrm{pL}=-\log \left[\mathrm{L}^{-\mathrm{n}}\right]$. Similarly, when the relations: (2) and (10):

$$
\left[\mathrm{Me}^{+u}\right]\left[\mathrm{OH}^{-1}\right]^{u}=K_{s o, u}
$$

are valid simultaneously at $\mathrm{pH}=\mathrm{pH}_{t 2}$, we have, by turns,

$$
\frac{\left(K_{l}^{\mathrm{H}}\right)^{d}\left[\mathrm{H}^{+1}\right]^{m d}\left[\mathrm{~L}^{-n}\right]^{d}}{\left[\mathrm{OH}^{-1}\right]^{c u}} \frac{\left[\mathrm{H}^{+1}\right]^{c u}}{\left[\mathrm{H}^{+1}\right]^{c u}}=\frac{K_{s o, c d}}{\left(K_{s o, u}\right)^{c}}
$$




$$
n \cdot \mathrm{pH}+d \mathrm{~L}=\left(p K_{s o, c d}+c u \cdot p K_{W}-c \cdot p K_{s o, u}\right) / d+\log K_{m}^{\mathrm{H}}
$$

Note that $\mathbf{M e}_{c}\left(\mathbf{H}_{m} \mathbf{L}\right)_{d}$ is identical with $\mathbf{M}_{n} \mathbf{L}_{u}$ at $c=n, m=0$, and then $d=u$ (see Equation (4)).

Equations (8) and (10) involve the term $n \cdot \mathrm{pH}+p \mathrm{~L} \quad$ on the left side and defined numbers on the right sideirrespectively on the $a, b, c, d, k$ and $m$ values. The same regularity is fulfilled, after all, for different sets of parameters: $a, b, c$ and $k$, in precipitates of $\mathbf{M e}_{\boldsymbol{a}}(\mathbf{O H})_{\boldsymbol{b}}\left(\mathbf{H}_{\boldsymbol{k}} \mathbf{L}\right)_{c}$ type, where $a u-b=c(n-k)$. From (6) we have

$$
\mathrm{pL}=-\log C_{\mathrm{L}}^{\bullet}+\log z_{\mathrm{L}}
$$

and then

$$
y=n \cdot \mathrm{pH}+p \mathrm{~L}=n \cdot \mathrm{pH}-\log C_{\mathrm{L}}^{\bullet}+\log z_{\mathrm{L}}
$$

In each case, $y=n \cdot \mathrm{pH}+p \mathrm{~L}$ is an increasing function of $\mathrm{pH}$. This means, in particular, that larger $y$ values correspond to larger $\mathrm{pH}_{t}$ values. This circumstance is particularly important when arranging the equilibrium solid phases along the $\mathrm{pH}$ axis, when the number of possible solid phases is $\geq 3$.

\section{Transition Point for Carbonates}

Many divalent cations form sparingly soluble carbonates $\mathbf{M e C O}_{3}\left(p K_{\text {so, } 11}\right)$ and hydroxides $\mathbf{M e}(\mathbf{O H})_{2}\left(p K_{\text {so,2 }}\right)$. In this case, we have:

$$
\begin{gathered}
{\left[\mathrm{Me}^{+2}\right]\left[\mathrm{CO}_{3}^{-2}\right]=K_{s o, 11}} \\
{\left[\mathrm{Me}^{+2}\right]\left[\mathrm{OH}^{-1}\right]^{2}=K_{s o, 2}} \\
z_{\mathrm{CO}_{3}}=1+10^{10.1-\mathrm{pH}}+10^{16.4-2 \mathrm{pH}} \\
C_{\mathrm{CO}_{3}}^{\bullet}=\left[\mathrm{CO}_{3}^{-2}\right] \cdot z_{\mathrm{CO}_{3}} \\
2 \cdot \mathrm{pH}+p \mathrm{CO}_{3}=p K_{s o, 11}-p K_{s o, 2}+2 p K_{W}
\end{gathered}
$$

The curve of $y=2 \cdot \mathrm{pH}+\mathrm{pCO}_{3}$ vs. $\mathrm{pH}$ relationship is plotted in Figure 1 at $C_{\mathrm{CO}_{3}}^{\bullet}=0.01 \mathrm{M}$. The numerical value of expression on the right side of Equation (18), related to defined $\mathrm{Me}^{+2}$ ion, forms a straight line parallel to $\mathrm{pH}$-axis (see Figure 1). The abscissa of the point of intersection of this line with the curve $y=2 \cdot \mathrm{pH}^{2} \mathrm{pCO}$ vs. $\mathrm{pH}$ relationship indicates the $\mathrm{pH}_{t}$ value, separating the $\mathrm{pH}$-intervals for $\mathbf{M e C O}_{3}$ and $\mathbf{M e}(\mathbf{O H})_{2}$, as the equilibrium solid phases. For example, $y=23.78$ calculated for the pair $\left(\mathbf{Z n C O} \mathbf{O}_{3}, \mathbf{Z n}(\mathbf{O H})_{2}\right)$ corresponds to $\mathrm{pH}_{t}=10.85$ (see Figure 1). The $\mathrm{pH}_{t}$ values found this way for different $\mathrm{Me}^{+2}$ ions are collected in Table 1 .

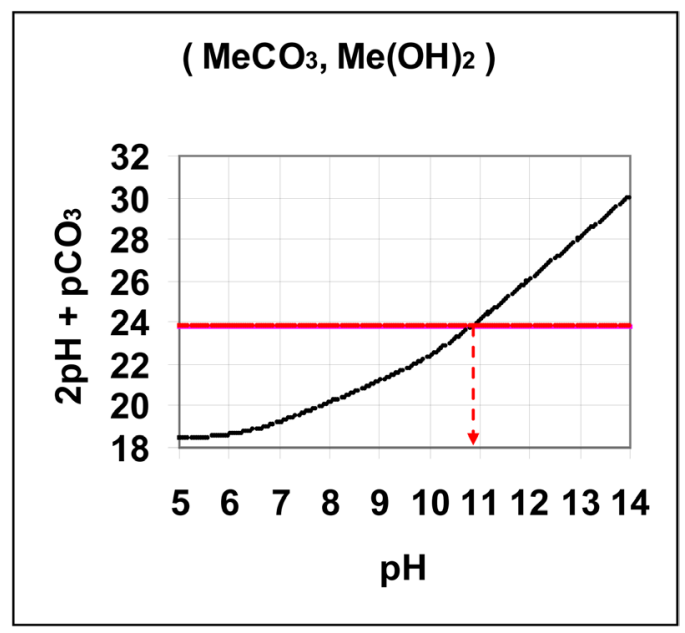

Figure 1. Location of $\mathrm{pH}_{t}=10.85$ value separating the $\mathrm{pH}$-intervals for $\left(\mathbf{Z n C O} \mathbf{O}_{3}, \mathbf{Z n}(\mathbf{O H})_{2}\right.$ ) pair (see Table 1). 


\begin{tabular}{|c|c|c|c|c|}
\hline \multirow{2}{*}{$\mathrm{Me}^{2+}$} & $\mathrm{MeCO}_{3}$ & $\mathrm{Me}(\mathrm{OH})_{2}$ & \multirow{2}{*}{$2 \mathrm{pH}+p \mathrm{CO}_{3}$} & \multirow{2}{*}{$\mathrm{pH}_{t}$} \\
\hline & $p K_{s o, 11}$ & $p K_{s o, 2}$ & & \\
\hline $\mathrm{Cu}^{2+}$ & 9.63 & 18.2 & 19.43 & 7.29 \\
\hline $\mathrm{Zn}^{2+}$ & 10.78 & 15.0 & 23.78 & 10.85 \\
\hline $\mathrm{Mn}^{2+}$ & 9.3 & 12.9 & 24.4 & 11.18 \\
\hline $\mathrm{Fe}^{2+}$ & 10.5 & 14.01 & 24.49 & 11.23 \\
\hline $\mathrm{Pb}^{2+}$ & 13.14 & 15.2 & 25.94 & 11.97 \\
\hline
\end{tabular}

\section{Transition Points for Lead Phosphates}

For $\mathrm{Me}=\mathrm{Pb}, \mathrm{L}=\mathrm{PO}_{4}(u=2, n=3)$ we have, among others, three solid phases: $\mathbf{P b H P O} \mathbf{H}_{4}, \mathbf{P b}_{3}\left(\mathbf{P O}_{4}\right)_{2}$ and $\mathbf{P b}(\mathbf{O H})_{2}$, defined by the solubility products:

$$
\begin{aligned}
& \mathbf{P b H P O}_{4}=\mathrm{Pb}^{+2}+\mathrm{HPO}_{4}^{-2} \quad\left(p K_{s o, 11}=11.36\right) \\
& \mathbf{P b}_{3}\left(\mathbf{P O}_{4}\right)_{2}=3 \mathrm{~Pb}^{+2}+2 \mathrm{PO}_{4}^{-3} \quad\left(p K_{s o, 32}=43.53\right) \\
& \mathbf{P b}(\mathbf{O H})_{2}=\mathrm{Pb}^{+2}+2 \mathrm{OH}^{-1} \quad\left(p K_{s o, 2}=15.2\right)
\end{aligned}
$$

In this system, the physicochemical data related to another solid phases: $\mathbf{P} \mathbf{b}_{5}\left(\mathbf{P O}_{4}\right)_{3} \mathbf{O H}$ and $\mathbf{P \mathbf { b } _ { 4 }} \mathbf{O}\left(\mathbf{P O}_{4}\right)_{2}$ as precipitates are also cited in literature [12] [13]; however, the solubility products for these species are formulated there in an unconventional manner. The unification of the solubility products to conventional notation will be the first, preparatory step for further considerations. The expressions for solubility products, formulated unconventionally, will be denoted as $K_{s o}^{*}$ (asterisked, with the corresponding subscripts, specifying their stoichiometric composition). We have:

$$
\begin{array}{ll}
\mathbf{P b}_{5}\left(\mathbf{P O}_{4}\right)_{3} \mathbf{O H}+\mathrm{H}^{+1}=5 \mathrm{~Pb}^{+2}+3 \mathrm{PO}_{4}^{-3}+\mathrm{H}_{2} \mathrm{O} & \left(p K_{s o, 531}^{*}=62.8\right) \\
\mathbf{P b}_{4} \mathbf{O}\left(\mathbf{P O}_{4}\right)_{2}+2 \mathrm{H}^{+1}=4 \mathrm{~Pb}^{+2}+2 \mathrm{PO}_{4}^{-3}+\mathrm{H}_{2} \mathrm{O} & \left(p K_{s o, 422}^{*}=36.86\right)
\end{array}
$$

and then

$$
\begin{gathered}
K_{s o, 531}^{*}=\frac{\left[\mathrm{Pb}^{+2}\right]^{5}\left[\mathrm{PO}_{4}^{-3}\right]^{3}}{\left[\mathrm{H}^{+1}\right]} \cdot \frac{\left[\mathrm{OH}^{-1}\right]}{\left[\mathrm{OH}^{-1}\right]}=10^{-62.8} \\
K_{s o, 422}^{*}=\frac{\left[\mathrm{Pb}^{+2}\right]^{4}\left[\mathrm{PO}_{4}^{-3}\right]^{2}}{\left[\mathrm{H}^{+1}\right]^{2}} \cdot \frac{\left[\mathrm{OH}^{-1}\right]^{2}}{\left[\mathrm{OH}^{-1}\right]^{2}}=10^{-36.86}
\end{gathered}
$$

The values:

$$
\begin{aligned}
& K_{s o, 531}=\left[\mathrm{Pb}^{+2}\right]^{5}\left[\mathrm{PO}_{4}^{-3}\right]^{3}\left[\mathrm{OH}^{-1}\right]=K_{s o, 531}^{*} \cdot K_{W} \quad\left(p K_{s o, 531}=76.8\right) \\
& K_{\mathrm{so}, 422}=\left[\mathrm{Pb}^{+2}\right]^{4}\left[\mathrm{PO}_{4}^{-3}\right]^{2}\left[\mathrm{OH}^{-1}\right]^{2}=K_{s o, 422}^{*} \cdot K_{W}^{2} \quad\left(p K_{s o, 422}=64.86\right)
\end{aligned}
$$

refer to the reactions: $\mathbf{P b}_{5}\left(\mathbf{P O}_{4}\right)_{3} \mathbf{O H}=5 \mathrm{~Pb}^{+2}+3 \mathrm{PO}_{4}^{-3}+\mathrm{OH}^{-1}$, $\mathbf{P b}_{4} \mathbf{O}\left(\mathbf{P O}_{4}\right)_{2}+\mathrm{H}_{2} \mathrm{O}=4 \mathrm{~Pb}^{+2}+2 \mathrm{PO}_{4}^{-3}+2 \mathrm{OH}^{-1}$ (see Appendix).

At $\mathrm{pH}_{t}$, we assume (this assumption will be verified later) that the solubility products for $\mathbf{P b H P O}_{4}$ and $\mathbf{P b}_{3}\left(\mathbf{P O}_{4}\right)_{2}$ are fulfilled simultaneously. From Equations (19), (20) and (13) we get:

$$
3 \cdot \mathrm{pH}+p \mathrm{PO}_{4}=3 p K_{s o, 11}-p K_{s o, 32}+3 \log K_{1}^{\mathrm{H}}
$$




$$
y=3 \cdot \mathrm{pH}-\log C_{\mathrm{PO}_{4}}^{\cdot}+\log z_{\mathrm{PO}_{4}}=3 p K_{\mathrm{so}, 11}-p K_{\mathrm{so}, 32}+3 \log K_{1}^{\mathrm{H}}
$$

where (see Equation (7))

$$
Z_{\mathrm{PO}_{4}}=1+10^{12.38-\mathrm{pH}}+10^{19.49-2 \mathrm{pH}}+10^{21.61-3 \mathrm{pH}}
$$

and $\left[\mathrm{H}_{i} \mathrm{PO}_{4}^{2-}\right]=K_{i}^{\mathrm{H}}\left[\mathrm{H}^{+}\right]^{i}\left[\mathrm{PO}_{4}^{3-}\right], \log K_{1}^{\mathrm{H}}=12.38, \log K_{2}^{\mathrm{H}}=19.49, \log K_{3}^{\mathrm{H}}=21.61$ (on the basis of [9], where $\mathrm{pK}_{1}=2.12, \mathrm{pK}_{2}=7.21, \mathrm{pK}_{3}=12.38$ ). The relation (24) agrees with Equation (9), for $\mathrm{L}=\mathrm{PO}_{4}$, $m=0, a=b=k=1, u=d=2, n=c=3$. Similarly, when assuming that the solubility products for $\mathbf{P b}_{3}\left(\mathbf{P O}_{4}\right)_{2}$ and $\mathbf{P b}(\mathbf{O H})_{2}$ are fulfilled simultaneously at $\mathrm{pH}=\mathrm{pH}_{t}$, we get:

$$
3 \cdot \mathrm{pH}+p \mathrm{PO}_{4}=0.5 p K_{s o, 32}-1.5 p K_{s o, 12}+3 p K_{W}
$$

The complete set of values for $y=3 \cdot \mathrm{pH}+p \mathrm{PO}_{4}$, related to different pairs of precipitates specified in Equations (19)-(23), is presented in Table 2. Comparing the y-values in the first line of Table 2, we state that the lowest value $\left(y_{1}=27.69\right)$ corresponds to the pair $\left(\mathbf{P b H P O} \mathbf{O}_{4}, \mathbf{P} \mathbf{b}_{3}\left(\mathbf{P O}_{4}\right)_{2}\right)$; this means that $\mathbf{P b}_{3}\left(\mathbf{P O}_{4}\right)_{2}$ follows $\mathbf{P b H P O}_{4}$ on the $\mathrm{pH}$-scale. Next, considering the $y$-values in the second line of Table 2, we state that the lowest $y$-value $\left(y_{2}=29.25\right)$ corresponds to the pair $\left(\mathbf{P b}_{3}\left(\mathbf{P O}_{4}\right)_{2}, \mathbf{P b}_{5}\left(\mathbf{P O}_{4}\right)_{3} \mathbf{O H}\right)$, i.e. $\mathbf{P b}_{5}\left(\mathbf{P O}_{4}\right)_{3} \mathbf{O H}$ is the next precipitate on the $\mathrm{pH}$-scale. Referring to the third line of Table 2, we state that the lower $y$-value $\left(y_{3}=33.45\right)$ corresponds to the pair $\left(\mathbf{P b}_{5}\left(\mathbf{P O}_{4}\right)_{3} \mathbf{O H}, \mathbf{P b} \mathbf{b}_{4} \mathbf{O}\left(\mathbf{P O}_{4}\right)_{2}\right)$, i.e. $\mathbf{P b} \mathbf{b}_{\mathbf{4}} \mathbf{O}\left(\mathbf{P O}_{4}\right)_{2}$ is the next precipitate on the $\mathrm{pH}$-scale. Finally, $y_{4}=44.03$ corresponds to the pair $\left(\mathbf{P b}_{4} \mathbf{O}\left(\mathbf{P O}_{4}\right)_{2}, \mathbf{P b}(\mathbf{O H})_{2}\right)$. From the curve in Figure 1, we find the transition points $\mathrm{pH}_{t i}(i=1, \cdots, 4)$ as the abscissas for $y=y_{i} \quad(i=1, \cdots, 4)$; the $\mathrm{pH}_{t i}$ values separating $\mathrm{pH}$ intervals of the equilibrium solid phases are specified in the lower part of the Table 2.

The curve of $3 \cdot \mathrm{pH}+p \mathrm{PO}_{4}$ vs. $\mathrm{pH}$ relationship is plotted in Figure 2 at $C_{\mathrm{PO}_{4}}^{\cdot}=0.01 \mathrm{M}$. In particular, the curve $y=3 \cdot \mathrm{pH}+\mathrm{pPO}_{4}$ intersects the line $y=3 \times 11.36-43.53+3 \times 12.38=27.69$ at $\mathrm{pH}_{t 1}=6.15$, separating the solid phases: $\mathbf{P b H P O} \mathbf{O}_{4}$ and $\mathbf{P} \mathbf{b}_{3}\left(\mathbf{P O}_{4}\right)_{2}$ in $\mathrm{pH}$-scale (see Table 2).

\section{Crossing the pH Scale}

In some cases, the precipitate of sparingly soluble salt is characterized by a relatively small solubility product value. Consequently, the $\mathrm{pH}_{t}$ value, separating the $\mathrm{pH}$ range of the salt and the corresponding hydroxide $\mathbf{M e}(\mathbf{O H})_{u}$ as the equilibrium solid phases, is significantly higher than the $\mathrm{pH}$ value, practically obtainable by addition of a strong base. In other instances, $\mathrm{Me}^{+u}$ ions form soluble hydroxo-complexes up to $\mathrm{Me}(\mathrm{OH})_{p}^{+u-p}$, characterized by the stability constant $K_{p}^{\mathrm{H}}$ value, with $p=\max \{j\}>u$. When $\mathrm{pH}$ value of the solution is high - the hydroxide is not an equilibrium solid phase when $\left[\mathrm{Me}(\mathrm{OH})_{p}^{+u-p}\right]=K_{\mathrm{so}, u} \cdot K_{p}^{\mathrm{OH}} \cdot\left[\mathrm{OH}^{-1}\right]^{p-u}>C_{\mathrm{Me}}$, where $C_{\mathrm{Me}}$ is the total concentration of Me in the system, $K_{s o, u}$ is defined by Equation (10).

\begin{tabular}{|c|c|c|c|c|}
\hline Precipitate & $\mathrm{Pb}_{3}\left(\mathrm{PO}_{4}\right)_{2}$ & $\mathrm{~Pb}_{5}\left(\mathrm{PO}_{4}\right)_{3} \mathrm{OH}$ & $\mathrm{Pb}_{4} \mathrm{O}\left(\mathrm{PO}_{4}\right)_{2}$ & $\mathrm{~Pb}(\mathrm{OH})_{2}$ \\
\hline $\mathrm{PbHPO}_{4}$ & $\begin{array}{l}3 \cdot p K_{s o, 11}-p K_{s o, 32} \\
+3 \cdot \log K_{1}^{\mathrm{H}}=27.69\end{array}$ & $\begin{array}{l}2.5 \cdot p K_{s o, 11}-0.5 \cdot p K_{W}-0.5 \cdot p K_{s o, 531} \\
\quad+2.5 \cdot \log K_{1}^{\mathrm{H}}=27.95\end{array}$ & $\begin{array}{l}2 \cdot p K_{s o, 11}+p K_{W}-0.5 \cdot p K_{s o, 442} \\
\quad+2 \cdot \log K_{1}^{\mathrm{H}}=29.05\end{array}$ & $\begin{array}{l}p K_{s o, 11}-2 \cdot p K_{W} \\
-p K_{s o, 2}+\log K_{1}^{\mathrm{H}}=36.54\end{array}$ \\
\hline $\mathrm{Pb}_{3}\left(\mathrm{PO}_{4}\right)_{2}$ & & $\begin{array}{l}5 \cdot p K_{s o, 32}-3 \cdot p K_{s o, 331} \\
\quad+3 \cdot p K_{w}=29.25\end{array}$ & $\begin{array}{l}2 \cdot p K_{s o, 32}+3 \cdot p K_{w} \\
\quad-1.5 \cdot p K_{s o, 422}=31.77\end{array}$ & $\begin{array}{l}0.5 \cdot p K_{s o, 32}+3 \cdot p K_{w} \\
-1.5 \cdot p K_{s o, 2}=40.965\end{array}$ \\
\hline $\mathrm{Pb}_{5}\left(\mathrm{PO}_{4}\right)_{3} \mathrm{OH}$ & & & $\begin{array}{l}0.5 \cdot p K_{s o, 531}+3 \cdot p K_{w} \\
-2.5 \cdot p K_{s o, 442}=33.45\end{array}$ & $\begin{array}{l}1 / 3 \cdot p K_{s o, 331}+3 \cdot p K_{w} \\
-3 / 4 \cdot p K_{s o, 2}=42.27\end{array}$ \\
\hline $\mathrm{Pb}_{4} \mathrm{O}\left(\mathrm{PO}_{4}\right)_{2}$ & & & & $\begin{array}{l}0.5 \cdot p K_{s o, 422}+3 \cdot p K_{w} \\
-2 \cdot p K_{s o, 2}=44.03\end{array}$ \\
\hline $\mathrm{PbHPO}_{4}$ & $\mathbf{P b}_{3}\left(\mathbf{P O}_{4}\right)_{2}$ & $\mathrm{~Pb}_{5}\left(\mathrm{PO}_{4}\right)_{3} \mathrm{OH}$ & $\mathrm{Pb}_{4} \mathrm{O}\left(\mathrm{PO}_{4}\right)_{2}$ & $\mathrm{~Pb}(\mathrm{OH})_{2}$ \\
\hline \multicolumn{2}{|c|}{$\mathrm{pH}_{t 1}=6.15$} & $=7.33$ & \multicolumn{2}{|c|}{$\mathrm{pH}_{t 4}=14.01$} \\
\hline
\end{tabular}

Table 2. Expressions for $y=3 \cdot \mathrm{pH}+\mathrm{PPO}_{4}$ formulated/calculated for different pairs of precipitates at the pre-assumed $\mathrm{pH}_{t i}$ values. 
As an example, let us take the precipitates: $\mathbf{Z n S}\left(p K_{\text {so1 }}=24.7\right)$ and $\mathbf{Z n}(\mathbf{O H})_{2}\left(p K_{\text {so } 2}=15.0\right)$. Applying $C_{\mathrm{S}}^{\cdot}=\left[\mathrm{S}^{-2}\right] \cdot f_{\mathrm{s}}=0.01, \quad f_{\mathrm{S}}=10^{19.97-2 \mathrm{pH}}+10^{12.92-\mathrm{pH}}+1 \quad\left(p K_{1}=7.05\right.$ and $p K_{2}=12.92$ for dissociation constants $K_{1}$ and $K_{2}$ of $\mathrm{H}_{2} \mathrm{~S}$ ), we get $y=2 \mathrm{pH}+p \mathrm{~S}=p K_{\text {so1 }}-p K_{\text {so } 2}+2 p K_{W}=24.37-15.0+2 \times 14=37.37$. The $\mathrm{pH}=\mathrm{pH}_{t}$ as abscissa related to this $y$-value is much higher than 14 (see Figure 3); what is more, it is much higher than $\mathrm{pH}$ values of a saturated strong base. Moreover, at high $\mathrm{pH}$ values, $\mathbf{Z n}(\mathbf{O H})_{2}$ is transformed into soluble complexes, mainly $\mathrm{Zn}(\mathrm{OH})_{4}^{-2}(p=4>2)$.

Another example is the system with precipitates: $\mathbf{C a C}_{2} \mathbf{O}_{4}\left(p K_{\text {so11 }}=8.64\right)$ and $\mathbf{C a}(\mathbf{O H})_{2} \quad\left(p K_{\text {so2 }}=5.26\right)$. Applying $C_{\mathrm{C}_{2} \mathrm{O}_{4}}^{\cdot}=\left[\mathrm{C}_{2} \mathrm{O}_{4}^{-2}\right] \cdot f_{\mathrm{C}_{2} \mathrm{O}_{4}}=0.01, \quad f_{\mathrm{C}_{2} \mathrm{O}_{4}}=10^{5.52-2 \mathrm{pH}}+10^{4.27-\mathrm{pH}}+1 \quad\left(p K_{1}=1.25, p K_{2}=4.27\right.$ for dissociation constants $K_{1}$ and $K_{2}$ of $\mathrm{H}_{2} \mathrm{C}_{2} \mathrm{O}_{4}$ ), we get $y=2 \mathrm{pH}+p \mathrm{C}_{2} \mathrm{O}_{4}=p K_{\text {so11 }}-p K_{\text {so2 }}+2 p K_{W}=31.38$ (see Figure 4); this value corresponds to $\mathrm{pH}_{t}=14.69$, related to calculated $\mathrm{pH}$ value of $4.9 \mathrm{~mol} / \mathrm{L} \mathrm{NaOH}$. The $\mathbf{C a}(\mathbf{O H})_{2}$ does not dissolve in an excess of strong base; $\mathrm{Ca}^{+2}$ forms only one hydroxo-complex, $\mathrm{CaOH}^{+1}$ $(p=1<2)$, and then $\mathbf{C a}(\mathbf{O H})_{2}$ is not dissolved in an excess of $\mathrm{OH}^{-1}$ ions.

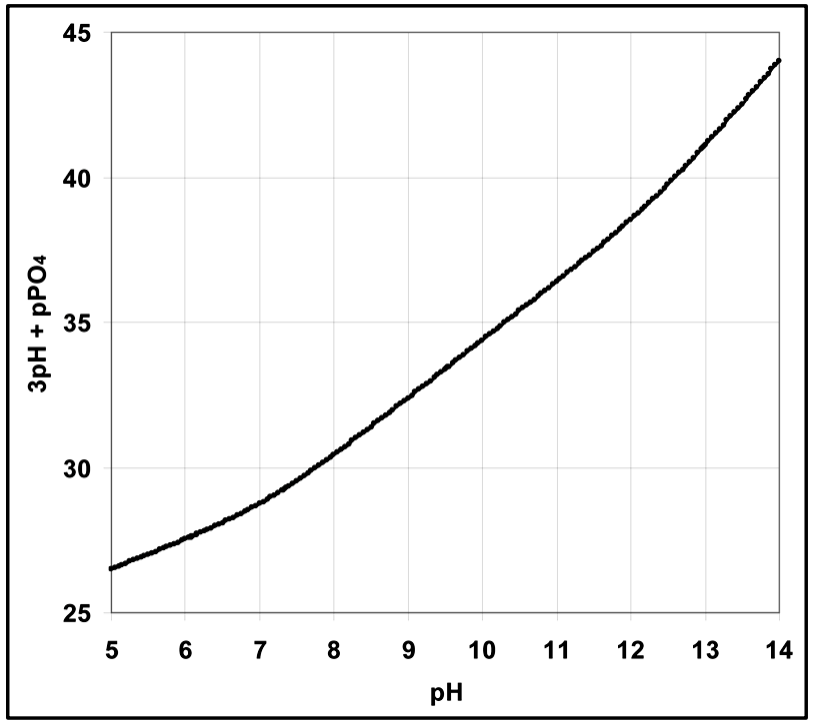

Figure 2. The curve $y=3 \cdot \mathrm{pH}+\mathrm{PO}_{4}$ vs. $\mathrm{pH}$, plotted at $C_{\mathrm{PO}_{4}}^{\cdot}=0.01 \mathrm{M}$.

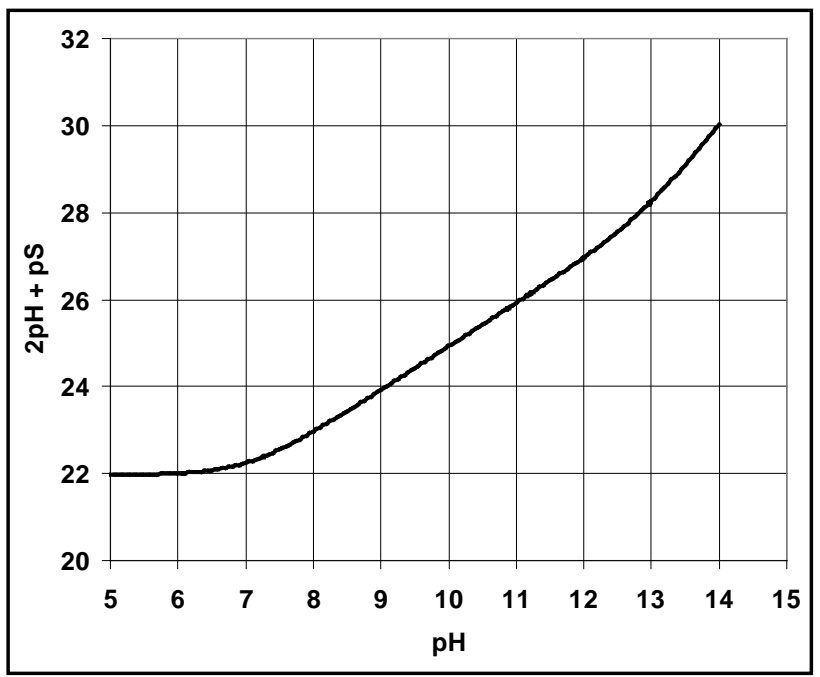

Figure 3. The curve $y=3 \mathrm{pH}+p \mathrm{~S}$ vs. $\mathrm{pH}$ plotted at $C_{\mathrm{S}}^{\bullet}=0.01 \mathrm{M}$. 


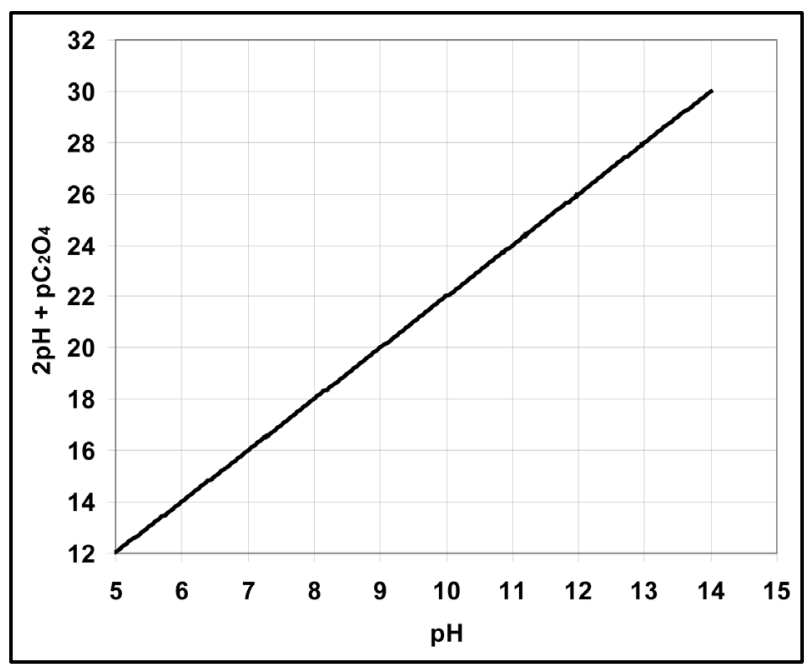

Figure 4. The curve $y=3 \mathrm{pH}+\mathrm{pC}_{2} \mathrm{O}_{4}$ vs. $\mathrm{pH}$ plotted at $C_{\mathrm{C}_{2} \mathrm{O}_{4}}^{\bullet}=0.01 \mathrm{M}$.

\section{Final Comments}

A simple, uniform method for determining the $\mathrm{pH}$ ranges of different precipitates as the equilibrium solid phases in aqueous systems with Me- and L-species is presented. The systems with two or more precipitates thus formed are discussed, together with the problem of ordering of appropriate precipitates along the $\mathrm{pH}$ scale. The above issues are applicable to the systems where soluble complexes of the $\mathrm{Me}_{a}\left(\mathrm{H}_{k} \mathrm{~L}\right)_{b}^{+a u-b(n-k)}$ and/or $\mathrm{Me}_{c}(\mathrm{OH})_{m} \mathrm{~L}_{d}^{+c u-m-d n}$ type are not formed or are relatively weak ones.

Solubility products can be defined in different ways. The lack of awareness of this fact can be a source of confusion, as results from examples taken from the literature. In particular, for the solubility product $K_{\text {so11 }}$ of $\mathbf{P b H P O}_{4}$ we find the following $p K_{\text {so11 }}$ values: 11.36 [14], and $\cdots 23.80$ [15]—both are referred allegedly to the dissociation reaction $\mathbf{P b H P O} \mathbf{O}_{4}=\mathrm{Pb}^{+2}+\mathrm{HPO}_{4}^{-2}$. The third value, which we denote as $p K_{s o}^{*}$, is significantly different from the previous ones; we can therefore assume that, in fact, it relates to dissociation reaction $\mathbf{P b H P O}_{4}=\mathrm{Pb}^{2+}+\mathrm{H}^{+1}+\mathrm{PO}_{4}^{-3}$. Indeed, after introducing the dissociation constant $K_{3}$ concerning the reaction $\mathrm{HPO}_{4}^{-2}=\mathrm{H}^{+1}+\mathrm{PO}_{4}^{-3} \quad\left(p K_{3}=12.38\right)$, we get $p K_{\text {so11 }}=p K_{\text {so11 }}^{*}-p K_{3}=23.80-12.38=11.42$, i.e., the value close to 11.36. The solubility product for $\mathbf{P} \mathbf{b}_{5}\left(\mathbf{P O}_{4}\right)_{3} \mathbf{O H}$ is also formulated improperly in [15].

\section{References}

[1] Michałowski, T. and Pietrzyk, A. (2006) A Thermodynamic Study of Struvite + Water system. Talanta, 68, 594-601. http://dx.doi.org/10.1016/j.talanta.2005.04.052

[2] Michałowski, T. and Asuero, A.G. (2012) Thermodynamic Modeling of Dolomite Behavior in Aqueous Media. Journal of Thermodynamics, 2012, Article ID 723052. http://www.hindawi.com/journals/jtd/2012/723052/cta/

[3] Michałowski, T. (2011) Application of GATES and MATLAB for Resolution of Equilibrium, Metastable and NonEquilibrium Electrolytic Systems. In: Michałowski, T., Ed., Applications of MATLAB in Science and Engineering, Chapter 1, InTech, Rijeka, 1-34. http://www.intechopen.com/books/show/title/applications-of-matlab-in-science-and-engineering

[4] Michałowski, T. and Lesiak, A. (1994) Formulation of Generalized Equations for Redox Titration Curves. Chemia Anali-Tyczna (Warsaw), 39, 623-637.

[5] Michałowski, T., Ponikvar-Svet, M., Asuero, A.G. and Kupiec, K. (2012) Thermodynamic and Kinetic Effects Involved with $\mathrm{pH}$ Titration of As(III) with Iodine in a Buffered Malonate System. Journal of Solution Chemistry, 41, 436-446. http://dx.doi.org/10.1007/s10953-012-9815-6

[6] Michałowski, T., Asuero, A.G., Ponikvar-Svet, M., Toporek, M., Pietrzyk, A. and Rymanowski, M. (2012) Principles of Computer Programming Applied to Simulated pH-Static Titration of Cyanide According to a Modified Liebig-Denigès Method. Journal of Solution Chemistry, 41, 1224-1239. http://dx.doi.org/10.1007/s10953-012-9864-x 
[7] Michałowski, T., Toporek, M., Michałowska-Kaczmarczyk, A.M. and Asuero, A.G. (2013) New Trends in Studies on Electrolytic Redox Systems. Electrochimica Acta, 109, 519-531. http://dx.doi.org/10.1016/j.electacta.2013.07.125

[8] Michałowski, T., Michałowska-Kaczmarczyk, A.M. and Toporek, M. (2013) Formulation of General Criterion Distinguishing between Non-Redox and Redox Systems. Electrochimica Acta, 112, 199-211. http://dx.doi.org/10.1016/j.electacta.2013.08.153

[9] Michałowski, T. (1982) Solubility Diagrams and Their Use in Gravimetric Analysis. Chemia Analityczna, 27, 39.

[10] Dirkse, T.P., Michałowski, T., Akaiwa, H. and Izumi, F. (1986) Copper, Silver, Gold and Zinc, Cadmium, Mercury Oxides and Hydroxides. Pergamon Press, Oxford. http://search.library.wisc.edu/catalog/ocm12945958

[11] Michałowski, T., Janecki, D., Lechowicz, W. and Meus, M. (1996) pH Intervals for Precipitates in Two-Phase Systems. Chemia Analityczna (Warsaw), 41, 687-695.

[12] Crannell, B.S., Eighmy, T.T., Krzanowski, J.E., Eusden Jr., J.D. Shaw, E.L. and Francis, C.A. (2000) Heavy Metal Stabilization in Municipal Solid Waste Combustion Bottom Ash Using Soluble Phosphate. Waste Management, 20, 135-148. http://dx.doi.org/10.1016/S0956-053X(99)00312-8

[13] Viellard, P. and Tardy, Y. (1984) Thermochemical Properties of Phosphates. In: Nriagu, J.O. and Moore P.B., Eds., Phosphate Minerals, Springer-Verlag, Berlin, 171-198. http://dx.doi.org/10.1007/978-3-642-61736-2_4

[14] Inczédy, J. (1976) Analytical Applications of Complex Equilibia. Horwood, Chichester.

[15] Saisa-ard, O. and Haller, K.J. (2012) Crystallization of Lead Phosphate in Gel Systems. Engineering Journal, 16, 161168. http://dx.doi.org/10.4186/ej.2012.16.3.161

\section{Appendix}

As an example, let us consider the pair of precipitates defined by Equations (22) and (23). We have, by turns,

$$
\begin{gathered}
{\left[\mathrm{Pb}^{+2}\right]^{5}\left[\mathrm{PO}_{4}^{-3}\right]^{3}\left[\mathrm{OH}^{-1}\right]=K_{s o 531} \rightarrow\left[\mathrm{Pb}^{+2}\right]^{20}\left[\mathrm{PO}_{4}^{-3}\right]^{12}\left[\mathrm{OH}^{-1}\right]^{4}=\left(K_{s o 531}\right)^{4}} \\
{\left[\mathrm{~Pb}^{+2}\right]^{4}\left[\mathrm{PO}_{4}^{-3}\right]^{2}\left[\mathrm{OH}^{-1}\right]^{2}=K_{s o, 422} \rightarrow\left[\mathrm{Pb}^{+2}\right]^{20}\left[\mathrm{PO}_{4}^{-3}\right]^{10}\left[\mathrm{OH}^{-1}\right]^{10}=\left(K_{s o, 422}\right)^{5}} \\
\frac{\left[\mathrm{Pb}^{+2}\right]^{20}\left[\mathrm{PO}_{4}^{-3}\right]^{12}\left[\mathrm{OH}^{-1}\right]^{4}}{\left[\mathrm{~Pb}^{+2}\right]^{20}\left[\mathrm{PO}_{4}^{-3}\right]^{10}\left[\mathrm{OH}^{-1}\right]^{10}}=\frac{\left(K_{s o, 531}\right)^{4}}{\left(K_{s o, 422}\right)^{5}} \\
\frac{\left[\mathrm{PO}_{4}^{-3}\right]^{2}}{\left[\mathrm{OH}^{-1}\right]^{6}}=\frac{\left(K_{s o, 531}\right)^{4}}{\left(K_{s o, 422}\right)^{5}} \rightarrow \frac{\left[\mathrm{PO}_{4}^{-3}\right]}{\left[\mathrm{OH}^{-1}\right]^{3}}=\frac{\left(K_{s o, 531}\right)^{2}}{\left(K_{s o, 422}\right)^{2.5}} \\
\frac{\left[\mathrm{PO}_{4}^{-3}\right]}{\left[\mathrm{H}^{+1}\right]^{3}}=\frac{\left(K_{s o, 531}\right)^{2}}{\left[\mathrm{OH}^{-1}\right]^{3}} \cdot \frac{\left(\mathrm{H}^{+1}\right]^{3}}{\left(K_{s o, 422}\right)^{2.5}} \rightarrow\left[\mathrm{H}^{+1}\right]^{3}\left[\mathrm{PO}_{4}^{-3}\right]=\frac{\left(K_{s o, 531}\right)^{2} \cdot\left(K_{W}\right)^{3}}{\left(K_{s o}\right)^{2.5}} \\
3 \cdot \mathrm{pH}^{2} p \mathrm{PO}_{4}=2 \cdot p K_{s o, 531}-2.5 \cdot p K_{s o, 422}+3 \cdot p K_{W}
\end{gathered}
$$


Scientific Research Publishing (SCIRP) is one of the largest Open Access journal publishers. It is currently publishing more than 200 open access, online, peer-reviewed journals covering a wide range of academic disciplines. SCIRP serves the worldwide academic communities and contributes to the progress and application of science with its publication.

Other selected journals from SCIRP are listed as below. Submit your manuscript to us via either submit@scirp.org or Online Submission Portal.
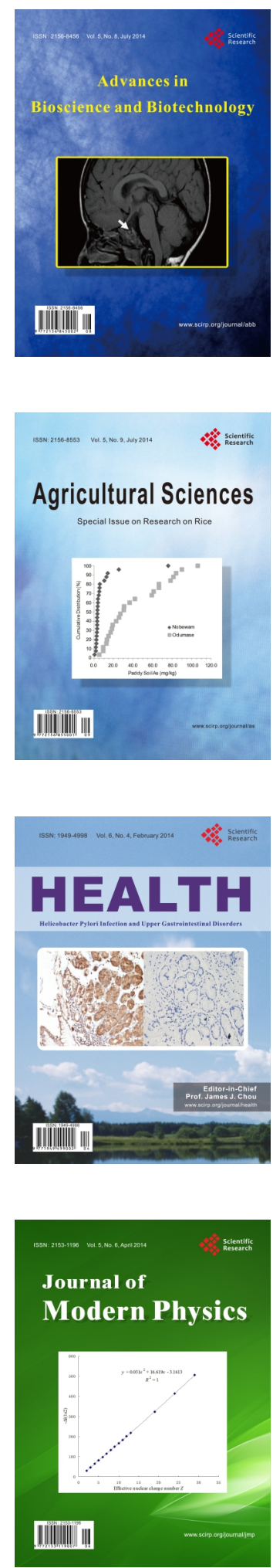
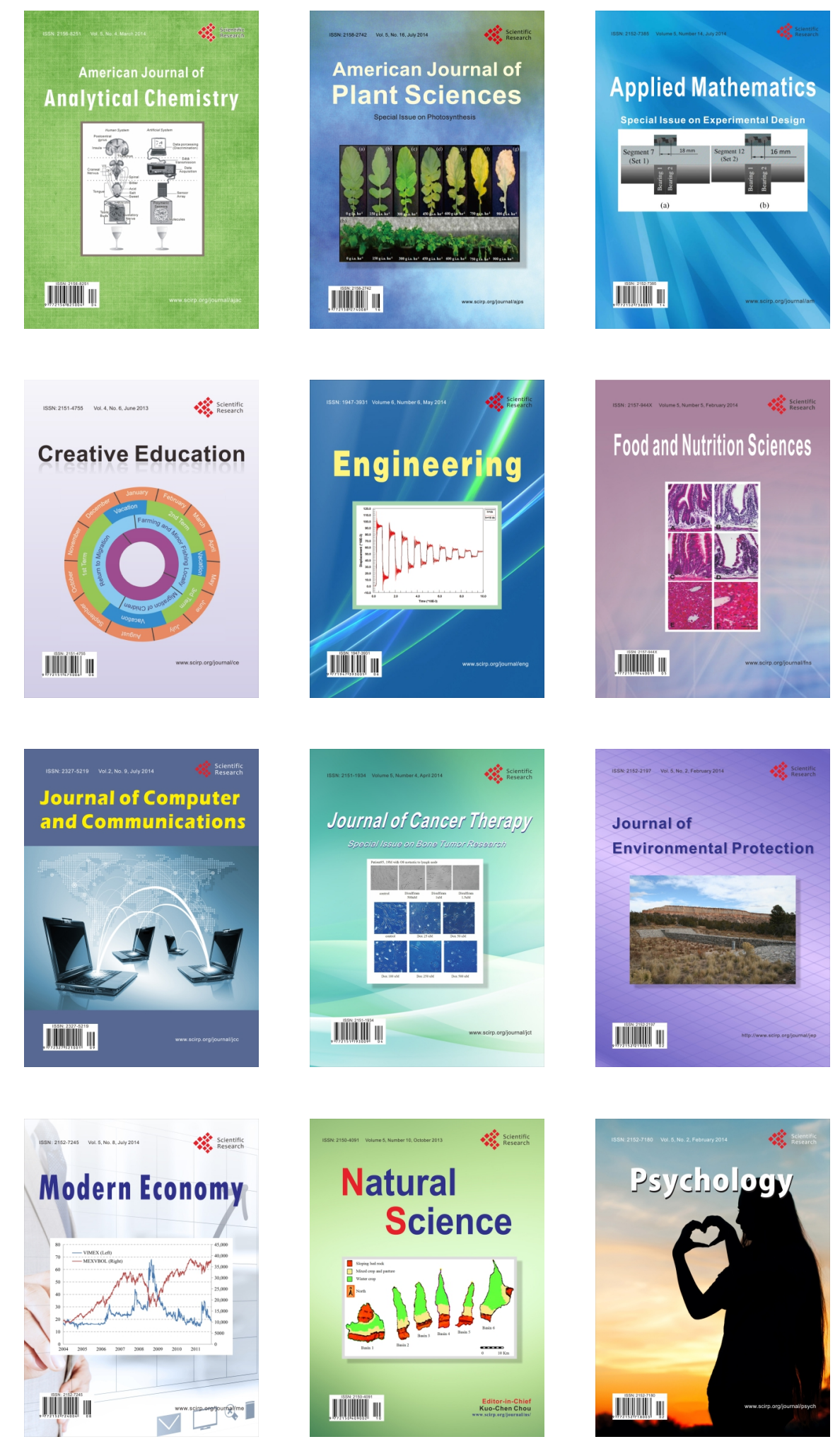